\title{
DEMOCRACY AND LANGUAGE IN JÜRGEN HABERMAS'S DISCOURSE THEORY
}

\begin{abstract}
The concept of hermeneutic science is outlined by Habermas as a reflection within the ordinary language, addressed to the dialogic dimension of intersubjective recognition and connected to the juridical guarantee. The guarantee function fulfilled by the discursive agreement towards every real dialogue is obvious: it indicates the main reference point for the regulation and coordination of social action, tracing a line of demarcation between being and having to be, facts and norms. Speech, communicative agreement and legal guarantee are mutually qualified terms where the public discussion of institutional issues makes it possible to define the normative validity as non-assimilatory generality, placed beyond any populistic yearning, tracing a line of demarcation between law and power. The idea of deliberative democracy expresses the relationship and distinction between the universalism of rights and the factuality of the norm issuing, between the idea of good and the idea of right, in order to support democratic decision-making legitimacy. Combining the reasons of the markets with those of civil solidarity, through independent forms of regulation both from the obsolete state sovereignties and from the traditional international perspectives, represents a primary challenge of the Habermasian theory where the critical role of the rational public sphere appears fundamental.
\end{abstract}

Keywords: language, discursive agreement, right, deliberative democracy, populism, public sphere.

\section{Introduction}

The practical-communicative reason is aimed, in Habermas, at the communicative examination of the structures of rationality inherent in the institutions and in the processes of social learning; it marks the distance between the strategic action, as instrumental context, directed to the attainment of subjective goals, and the communicative action directed to the rational consensus and connected to the juridical guarantee. The idea of $d e-$ liberative democracy expresses the relationship and the distinction between 
the universalism of rights and the factuality of standardization, supporting democracy for decision-making legitimacy. The democratic procedures are the medium between public autonomy and private autonomy in such a way that the recipients of the decision can be understood as the authors of the same. However, this process presupposes the action of a critical public sphere, capable of mediating between the formation of political opinions and wills and their expression in legally binding decisions, giving voice to the potential of social emancipation inherent in communicative action. This constitutes a problematic nucleus of Habermas's theory of discourse: in complex society, in fact, a functional language is employed, indifferent to the debate between public spheres to which there remains a mere media space of survival which debases the legal guarantees in empty form. The global public sphere appears progressively depoliticized and coincides with the private sphere of action, exposed and sensitive to the calls of populist movements. Combining the reasons of the markets with those of civil solidarity - through forms of regulation independent of both obsolete state sovereignties and traditional internationalist perspectives - represents a primary challenge of the Habermasian theory.

\section{Hermeneutic science and communicative rationality}

Language, which in Habermasian theory assumes the role of intersubjective understanding, can be conceived as a guide of norm-oriented social action or as a means of transferring information (Habermas, Luhmann, 1983, p. 187) ${ }^{1}$. The theory of communicative action is defined by Habermas as "the search for the historical function and efficacy of those 'structures of rationality' which, based on the processes of collective learning, interact with the functional imperatives of the system $[$ System $]$ and are available to become driving factors of historical evolution" (Kirkpatrick, 2003, p. 91112). It is to specify that the processes of social integration, belonging to the life-world [Lebenswelt], differ from the processes of systemic integration (Accarino, 1983, p. 110). Habermas emphasizes the conflict - understood as a cognitive dissonance, symptom and expression of the tension between the systemic control mechanisms and those of social regulation - between the instrumental domain, formally organized and not yet integrated by the communicative agreement, gathered in a sociality without norms (Habermas, 1986, p. 959) from the cognitive context of the life-world that is presumed to be supported by inclusive and equal communicative interactions. Through the introduction of practical-communicative reasoning, the author 
marks a critical distance from the negative dialectic of the Frankfurt School (Rasmussen, 1993, p. 51) ${ }^{2}$ orienting himself to the communicative analysis of the structures of rationality inherent in the institutions and processes of social learning (Rusconi, 1980, p. 8). Central is the delineation of the concept of hermeneutics as a reflection that arises within natural languages and that differs from the scientific interpretation of phenomena (MacCormick, 1981, p. 34; Hart, 1982). In fact, the distinction between empirical-analytical science and hermeneutic science appears clear, where the first aims at the production of technically exploitable knowledge and represents the systematic continuation of prescientific learning processes in the context of instrumental action, hermeneutic science, on the other hand, is aimed at the production of knowledge understood as a process, always incomplete, of self-reflection and understanding of otherhood, prescientifically exercised in the traditional context of symbolically mediated interactions, that is in the context of ordinary language (Donolo, 1971, p. 14; Grondin, 1994, p. 103146; Waizbort 2004, p. 151-162; Bube, 2008, p. 139-166). The distinction between scientific theories and communicative theory must be introduced here: the first supported by languages and expert knowledge aimed at an effective transformation of the objective world, the second aimed at subjective and social self-clarification, understood as emancipation from communicative conditioning (Geuss, 1989, p. 91; Scheurman, 2006, p. 85-105). Ordinary language always appears in excess of the objectifying languages of science in that it is openly communicative to its own interpretative possibilities. Habermas does not seem to underestimate the reflection potential inherent in traditional scientific knowledge, nor diminish empirical research or properly technical disciplines. The author, rather, rejects scientism, that is, the monological absolutization of scientific knowledge and the claim of universalization of the underlying rationality standards (Agazzi, 1983, p. 12) proposing an idea of communicative rationality based on the intersubjective understanding which feeds on the properties and linguistic flexibility of natural language (Keul, 2002, p. 253-66). Hermeneutic science also differs from linguistics - which describes the technical competence of language in that it is pointed towards a critical reflection as a communicative competence. The hermeneutic approach is based on the understanding of the structures of everyday language that allows us to detect the universal parameters of linguistic rationality: through the respect of these criteria, we can develop an authentic impulse of social emancipation inherent in the very structure of language (Privitera, 1983, p. 187). The meaning, which directs the action, becomes accessible through ordinary language and in everyday linguistic practice: they represent different moments of the same 
linguistic game (Habermas, 1980, p. 165-205); therefore Habermas defines the language as "a kind of meta-institution on which all social institutions depend" (Habermas, 1980, p. 256).

\section{Strategic action and communicative action}

The correspondence between the problem of the theory of society, about the way to guarantee the social order, and the problem of the theory of action on social interaction should therefore be emphasized. Both can be directed by strategic-functional action [strategisches Handeln], or by communicative action [kommunikatives Handeln]. In the first case, the strategic coordination of actions depends on utilitarian calculations aimed at operational success [erfolgsorientiertes Handeln] (Habermas, 1997, p. 142). In communicative action, otherwise, individual actions turn to the rationally motivated agreement (Habermas, 2000a, p. 142). Communicative action represents the discursive context of understanding (Habermas, 1992a, p. 112) in which subjects communicate rationally to understand each other, assuming the sharing of the ideal communicative situation [Verständigung] as a criterion of truth, of rationality and of freedom of action (Geuss, 1989, p. 66-67). Given the co-implication of communicative theory and linguistic praxis, the logic of discourse is defined as a pragmatic logic, based on the relevance of the best argument, on the rational motivations that form the background to the decisions. "The positive outcome of a discourse, its ability to acquire consensus is not to be sought in logical cogencies or in empirical evidence, coming from the outside, but in the strength of the best argument. This force coincides with rational motivation" (Rusconi, 1982, p. 56). The argument is rational when, through the reference linguistic systems, it runs through all the possible levels of discussion until consensus is reached, understood as that situation in which theses, judgments and points of view are presented in non-imperative way, but as proposals that require legitimacy through the critical judgment of the public (Privitera, 2001: p. 157).

\section{Discursive consensus}

There is a genuine consensus only when, with the mastery of formal properties of discourse, free movement between the levels of discourse is guaranteed, as in the ideal linguistic situation. "The formal properties of discourse must therefore be of such a nature that the level of dis- 
course can be changed at any time and that a linguistic-conceptual system, chosen first, can in any case be recognized as inadequate and revised: progress in substantive knowledge is accomplished in the form of a substantial linguistic critique" (Habermas, 1980, p. 331). Therefore, the discursive procedure is not aimed at revealing the truth of the statements, but rather at confirming their rational acceptability. "Convincing is what we can accept as rational" (Habermas, 2007, p. 51). To the classic logical categories of possible/impossible/necessary, Habermas replaces adequate/inadequate/stringent arguments (Ceppa, 2004, p. 142), describing a logic of the relevance or adequacy of an argument towards the linguisticconceptual reference system (Habermas, 1980, p. 322). An action, or a linguistic statement, are defined as rational when they are discursively justified, so that communicative rationality and argumentation belong to each other. However, the character of acceptability, referred to the argumentative praxis, does not coincide with the arbitrariness of decision-making (Habermas, 2007, p. 23): the Habermasian analysis of the argument identifies the prepositional truth and the ethicality of the action with the consent rational, placed at the base of the validity and legitimacy of the rules of action. From this derives the indispensable presence, at least potential, of the listener, able to confirm or deny the arguments: this, abandoning the perspective of the observer in favor of that of the participant, enters the world-of-life shared intersubjectively by the linguistic community (Habermas, 2007, p. 23). The spiral process, thus described, underlines the "intermittent" character of the intersubjectivity carried out in the dialectic between the universality of the communicative rules and the particularity of linguistic contexts, as well as the inseparable link between communicative tradition and translation by application languages. "The fact that in general there is something like a tradition includes a moment of non-mandatory" (Habermas, 2007, p. 23). It is precisely this moment of non-obligation that allows the opening of the speech to the reply of the recipient; it is the "intermittent" character of intersubjectivity that allows for discursive consent and understanding. This process thus exceeds the information function and expresses the linguistic game between theory/practice, tradition/translation, ordinary language/expert languages. "The intersubjectivity of communication in ordinary language is something fragmentary. It exists because an agreement is always possible in principle (...). The hermeneutic understanding is inserted at the points of interruption, compensating for the fragmentation of intersubjectivity" (Habermas, 2007, p. 23). The formalized languages, on the other hand, transmit a static and resolved information in what is conveyed by the linguistic medium: only the ordinary language belongs to the dia- 
logic dimension of intersubjective recognition and reciprocity of behavioral expectations, directly connected to the legal guarantee. In this function, ordinary language does not only represent a mirror of reality, but offers the gateway to the world (Habermas, 2004a, p. 5) and expresses, in the always present tension between real and ideal communication, all the critical potential of the Habermasian theory. The concept of social institution appears, in fact, suspended between the counterfactuality of the communicative ideal and the need for its own practical realization through the conditions of functional reproduction of power. It follows that institutions can assume an emancipatory value only through the intervention of a public sphere capable of countering the technocratic and ideological domination (Carmagnola, 1983, p. 48) $)^{3}$.

\section{Public sphere and complex society}

In the complex society, in which personal ties appear sparse and weak, the task of reproducing the modern forms of collective identity lies with public opinion and institutionalized processes of formation and expression of will, so much so that, according to Habermas, the critical state of a democracy is detected precisely by the vitality of the corresponding public and political sphere (Habermas, 2004a, p. 9). "The quality of a democracy is not measured only by respect for certain essential procedural conditions, but by the quality of the public discourses that accompany institutional decisions and which can, to varying degrees, give them a basis of legitimacy" (Floridia, 2017, p. 225). The public sphere places itself in a cooperative relationship with the political system, as a "periphery" of the same, in order to allow the circulation of discourses from the bottom up and vice versa, in a multi-level system, which from ordinary speech, through the mediation of "weak" public discourses, reaches political and juridical institutionalization (Habermas, 2006, p. 415). The facilitator role of the public sphere is specified in the mobilization of relevant principles, information, requests and interpretations that predispose the political agenda, ensuring its discursive pluralism (Habermas, 2006, p. 416). In turn, the political system, since it ultimately depends on the processes of democratic legitimization of decisions, can take advantage of that gap in civil society, which is represented by the "irregular life" of the public sphere (Habermas, 2006, p. 417). The public sphere operates, therefore, as a filter, as a hydraulic link between the formation of political opinions and wills and their expression in legally binding decisions, always subject to discursive revision. In other words, it 
works as a "laundering" of the "muddy elements" of political communication, that is, of the themes and contributions to be reported as relevant to the more properly political and legal sphere (Habermas, 2006, p. 416-418): to the latter the task of translating the discussion materials into institutionalized decisions is assigned, placing the model of deliberative democracy as an ideal criterion of decision-making correctness (Rasmussen, 2008, p. 73). The double track, delineated by the public sphere, does not mark an obvious dividing line between the public sphere and the institutional sphere, but marks a communicative circularity between opinions and decisions, between public and private (Floridia, 2017, p. 246), that is, a plan of discursive intersection between the cognitive potential and the empirical and normative content expressed by deliberative democracy.

\section{The mediation of public sphere}

The reflective mediation of public space, between the political system and civil society (Habermas, 2006, p. 418), between general interests and particular positions, could, in the concreteness of social life, be translated into a strategic model of information and distortion of communicative dynamics (Habermas, 2006, p. 419). It is common experience, in fact, that functionally oriented systems and groups of expression of particular interests can use languages and knowledge aimed at influencing the political system, going beyond the information channels (Habermas, 2006, p. 419). In such cases, the pseudo-consensus of communicative processes bent to particular interests must be distinguished from the consent of the speakers in the discourse that precedes the ideal linguistic situation and that is obtained, according to Habermas, through the procedural correctness of the practices of expression and the formation of the collective will. On the contrary, far from adopting a discursive perspective, the complex society uses a functional language, indifferent to the debate between public spheres, often in conflict of interest, to which a mere media space of survival remains. Political power, originated in this case outside the traditional channels of democratic discussion of decisions, coincides with social visibility and with a personalized and spectacular policy where popular sovereignty is reduced to the acclamation of leader and guarantees of the right are substantially emptied and reduced to mere form. "Visibility is the real purpose of the public appearance. The price consists in accepting the fusion of private life with public life", where political issues are assimilated to ways and contents of entertainment (Habermas, 2006, p. 422; Luhmann, 1996). 


\section{The colonization of the public sphere}

The colonization of the public sphere, carried out by the economicfinancial system, leads to a paralysis of civil society due to the "intrusion" of market imperatives in the production and distribution of messages addressed to the public. "The markets take on increasing functions in areas of life that, so far, have been held together by law, then with politics or with pre-political forms of communication. In this way, not only are the private spheres increasingly moved towards mechanisms of action aimed at the pursuit of success and oriented by individual preferences; even the area subject to the constraint of public legitimacy is shrinking. The absolutization of the private citizen's perspective [Privatismus] is attributable to a progressively depoliticized public sphere coinciding with the private sphere of action and is reinforced by the discouraging loss of effectiveness of a process of democratic formation of decisions and opinions" (Habermas, Ratzinger, 2005, p. 51-52). This leads to the restriction of the common space of dialogue and the loss of effectiveness of the institutions responsible for the democratic representation of interests. The political system, as well as the legal system - which should derive its legitimacy from the first, snatching the right to coincide with the fact - subtract themselves from the peculiar function of representing social instances and guaranteeing behavioral expectations with the support to a contingent ordering of power relations. "As soon as faith in the legitimacy of an existing order disappears, the latent violence introduced into the system of institutions is freed, either in the form of violence manifested from above (which is possible only temporarily) or in the form of a widening of the margins of participation" (Habermas, 1976, p. 106).

\section{Public sphere and populist movements}

If the socializing force of communicative action is frozen in the spheres of private life, social actors will be controlled and plebiscitarily mobilized (Habermas, 1996, p. 438). Populist temptations represent, from below, a response to the progressive social eradication and, from above, a reaction to the loss of centrality of political and democratic institutions and to the evasiveness of global powers towards collective obligations and responsibilities (Urbinati, 2014). Populist movements "blindly defend the ossified traditions of a world of life threatened by capitalist modernization. These movements are as modern in their forms of mobilization as they are undemocratic in 
the aims they propose" (Habermas, 1996, p. 440). The force of the grip of populism is found in a speech of criticism of the asphyxiated procedural democracy, detached from the values and contents that give substance to popular sovereignty, and aimed at reconstituting the collective ties between those excluded by the global elites by encouraging conflict and social polarization (Müller, 2017, p. 8). This misleads Habermas's teaching that the idea of the people as a single and homogeneous subject represents a dangerous fantasy since the people can exist only in the plurality of their voices. Only a decisive struggle against social inequality - which in Habermas coincides with a supranational cooperation capable of offering a socially acceptable political form to economic globalization - may be, according to the author, a reasonable alternative to both wild financial capitalism and the recovery of a presumed sovereignty of the national state, eroded for a long time (Habermas, 2017, p. 7-12). Ultimately, if on the one hand, the boundary line that separates the political system from the public sphere, while revealing itself as permeable and porous, appears well defined and not to be populistically circumvented (Habermas, 1996, p. 427; 442), on the other hand, the urgency of effective public discourse involvement in global decisions emerges. The public sphere, although exposed and determined by repressive effects generated by social powers that affirm their imperatives against or outside any democratic and discursive procedure (Habermas, 1996, p. 417-419), appears to be the indispensable medium of a non-forced communication [uneingeschränkter] and expression of the potential inherent in communicative action.

\section{Virtual public sphere}

The Internet, in this area, seems to have contributed to the expansion of the public sphere, as well as having counterbalanced the impersonal and asymmetric character of media communication - entrusted to the practices of opinion democracy, the trivialization of the charismatic power and the efficacy of the slogans (Minc, 1998) - introducing some deliberative elements aimed at an audience of writers and web readers (Habermas, 2006, p. 423). It should be noted, however, that this, in itself, does not automatically create a progress in the public sphere: this condition, in fact, if on the one hand, offers a contribution to the delineation of an inclusive and accessible public sphere, on the other hand it provides the side to an increased discursive fragmentation and to centrifugal movements translated into isolated individuals and policies (Habermas, 2006, p. 423; Dahlgren, 
2005 , p. 148-152). The web would thus fragment public opinion on central issues, describing archipelagos dispersed in the sea of digital noises, far from the conscious assumption of generally binding decisions (Habermas, 2006; Mazzei, 2006, p. 1-5). This is confirmed by a reduced political participation in the mere online presence and expressed with a "Like", in the creation of virtual and radicalized communities or similar, in the determination of information chains in which the news loses its original meaning by being distorted (fake news), in the increasingly frequent cases of online defamation, cyber-bullying and persecution of the criticized subjects (trolls) (Bauman, Leoncini, 2017, p. 73-78). "What is lacking in these communicative spaces (closed in themselves) is the inclusive glue, the inclusive strength of a public sphere that highlights which things are really important. To create this 'concentration', one must first know how to choose know and comment - the themes, contributions and information that are relevant" (Habermas, 2014, p. 2). One of the problematic nuclei of Habermas's theory is, then, represented by the relationship between language and power, referring to a globalized social sphere in which the privileged sectors of possession and production are constituted by the capacity to inform and be informed (Gorz, 2003; Rifkin, 2002; Vandenberghe 2002). Beyond the Habermasian idea of language as a tool for the cooperative search for truth, it would be necessary to ask how the rules of global communication are established, and by what subjects, that is, how language and the legal system can guarantee communication exchanges in social contexts conditioned by economic praxis and functionalistic rationality. "Democratic procedures and institutions can be reduced to empty facades if they fail to have a functioning public sphere. On the other hand, the functioning of the public spheres presupposes always demanding conditions of a normative nature. In fact, public communication circuits should not be cut off from actual decisionmaking processes" (Habermas, 2014, p. 1).

\section{Deliberative democracy}

Individual freedoms are accompanied by the political participation of citizens in decision-making processes that express the discursive formation of the will as a communicative power [kommunikative Macht]: through this procedure, the recipients of the decision can be understood as the authors of the decision (Habermas, 1997, p. 143; Habermas, 2000c, p. 9; Norval, 2012 , p. 802-810). In other words, democratic procedures are the medium between the interest of the individual and the interest of the citizen, be- 
tween public autonomy and private autonomy (Habermas, 1992c, p. 99). "No one is free until everyone enjoys equal liberty" (Habermas, 2000c, p. 15). The principles of the rule of law and democratic systems are thus constitutive and expressed by the process of democratic self-regulation (Habermas, 2000c, p. 12). "Since the decisive idea is the autonomy of citizens, legal norms must be made in such a way that they can be accepted simultaneously both as laws of duress and as laws of freedom" (Habermas, 2004b, p. 106-107). The result is the juridical institutionalization of networks of discourses, specified on the material, social and temporal levels, in which "the wild communication circulations" of the public spheres integrate dialogically with the formalized procedures of consultation and deliberation: from the interaction of the same comes the political and normative legitimacy (Habermas, 2000c, p. 99). The public space of the discourse shows the internal link between language, the public sphere and its expression in democratic decision-making procedures, i.e. the circularity between procedures, legitimate decisions and the discursive formation of political opinions and wills (Habermas, 1971, p. 3; 1996, p. 152-56). In the relationship between law and politics, the legal institutionalization of deliberative policy procedures draws its legitimizing force from the idea of rational self-regulation (Kalyvas, 2001, p. 1-19), which refers to the common discursive origin of public and private autonomy, to the proper link, in a democratic state of law, between "rule of law" and popular sovereignty (Habermas, 2007, p. 123). The law "cannot be legitimate if it is not produced in a legitimate way, that is, according to those training procedures of opinion and will that justify the presupposition of a rational acceptability of the results. The authorization to political participation is thus linked to the expectation of a 'public use' of reason: as democratic co-legislators citizens cannot reject the informal solicitation [ansinnen] to move towards the common good" (Habermas, 2000c, p. 16; Habermas, 2004b, p. 99-100; Habermas, 1997, p. 20). In this way, normative validity and democratic legitimacy are intrinsically connected in the Habermasian ideal of deliberative democracy, which indicates, as a parameter and stimulus, the gap between the decision and its ideal overcoming in the discourse (Müller-Doohm, 2015, p. 3). "The cooperative research of citizens deliberating on solutions to political problems takes the place of the aggregation of preferences of private citizens or the collective self-determination of an ethically integrated nation" (Habermas, 2006, p. 413). The existence of the democratic state of law derives from the discursive motivations of a community already accustomed to civil and political liberties as "non-coercible" structures of a civil society not bent to systemic imperatives (Habermas, 1996: 546). Implicit, 
but clear, is the reference to vital communicatively receptive worlds, that is, rationalized and emancipated from power relations (Habermas, 1996, p. 357). The constant tension between facts and norms, between legality and discursive legitimacy, stands as a constitutive trait of social and historical reality and constitutes the focus of deliberative politics in the frame of discursive interactions between formal procedures and informal networks of expression of the collective will, in the democratic state of law (Floridia, 2017, p. 195-206).

\section{Deliberative democracy and communicative peripheries}

The normative content of the concept of democracy is not restricted, in this way, to the institutional arrangements of the democratic state, but it is extended to embrace the more decentralized circuits of public communication, where the purpose of the cooperative search for truth, which coincides with the best argument, is pursued with the openness of institutions to the most disparate themes, values and contributions (Habermas, 1992b, p. 451). Of course, decision-making responsibility refers to the formalized context: speeches do not govern (Habermas, 1992b, p. 452), but they generate communicative power capable of influencing the apparatus of the administrative system through procedures. In other words, the deliberative component [Deliberative Komponente] has its own legitimizing force, which is expressed in the legislative procedures. "This is the model of a policy based on deliberations. It no longer starts from the macro-subject of a totalitarian community, but from anonymous discourses that integrate each other. It bears the greater burden of normative expectations on both the procedures of democracy and the infrastructure of a political 'public sphere' that informally draws on spontaneous sources" (Habermas, 1992c, p. 123-24). In this way, the hierarchical regulatory instance, proper to state power, and the decentralized one of the market should be accompanied by civil solidarity and orientation to the common good, derived from the communicatively achieved consensus, as forces of social integration (Habermas, 1996, p. 301). Two orders of objections arise from Habermas's statements about the representative efficacy of the binomial formal institutions / informal public sphere. On the one hand, the public sphere appears to be conditioned by the power of the media, aimed at mass retention and the support of consumption, rather than seeking discursive consent; on the other hand, the questioning, in the global context, of the traditional formulas of expression of the common will is reflected in the evident apathy of civil society towards 
democratic institutions. A central issue, beyond the Habermasian direction, is the current crisis of the traditional mechanisms of political representation. In this regard, it should be remembered that in a complex society, a "sovereignty without a subject", able to condition the formation of opinion and the public will, is exercised not only by communication contexts, but by those sectors that more than others are able to affirm an instrumental and strategic rationality. Habermas himself underlines the need for a global policy capable to stand up critically towards the dynamics of economic and financial power and refers to the urgency of institutionalized procedures that allow social actors to avoid "creative destruction" by extending particular preferences and interests to a dimension of global governability (Habermas, 2000b, p. 25; Habermas, 2004b, p. 133). The real conditions of tragic indigence in which a large part of the world population finds themselves, however, seem to render the criteria of symmetry, reciprocity and reversibility of subjective positions in discourse mere positions of principle (Mendieta, 1999, p. 145). The parameters of abstract and contractual equality would testify, for the most part, the exceptional situation of the most developed societies. Not without irony, adds Habermas, "how can a responsibly democratic politics 'be reborn' behind globalized markets [...] is a problem that requires, on an analytical level, a great deal of political skills and institutional fantasy" (Mendieta, 1999, p. 146). The law of the global society, rather than corresponding to democratic processes of formation and expression of the collective will, assumes the characteristics of a product that is always unfinished and never completely pre-determinable through the same normative premises that describe frame rules in which communicative emptiness is expressed. The central question is whether it is still possible to define the legal context through substantial protection of social relations or whether this sector is open to the normalization of any content imposed by productive urgency, in an essentially entrepreneurial perspective (Ferrarese, 2002, p. 95).

\section{Conclusions}

In conclusion, one wonders whether globalization, mainly of economicfinancial processes, can lead to the formulation of generally inclusive normative criteria, in the sense of discourse ethics, that will be used as critical and proposal elements (Habermas, 1997, p. 131), or if instead it does not represent the start of a social modernization capable of profoundly weakening the forms of democracy as well as the bonds of social solidarity be- 
tween citizens, determining "the transformation of the citizens of liberal societies into isolated monads, which act only on the basis of their own interest and use their individual rights as weapons towards others" (Habermas, Ratzinger, 2005, p. 51). In other words, it is a matter of understanding whether and to what extent a widespread deliberative praxis - a discursive and public formation of opinions and wills, but also a democratically institutionalized formation of these opinions and wills - is able to compete with other powerful mechanisms belonging to the social order (Floridia, 2017, p. 236). In this regard, the firm distinction between communicative power and administrative power, carried out by Habermas, and the delineation of the public sphere as a mainly informal sphere (Habermas, 1996, p. 423; 429) seem to flatten the functions of the executive over those of its purely technical and bureaucratic component. Moreover, they seem to reserve the heart of the political decision almost exclusively to the legislative dimension, by not taking into due consideration the relevance of fully political governance networks which, as such, are supported by democratic and deliberative logic or, on the contrary, governed by the logic of bureaucratic command and bargaining between interests (Floridia, 2017, p. 250). Considering the possible development of forms of deliberative governance could lead to an innovative institutional articulation of collective opinions and choices (Floridia, 2017, p. 251-253). The valorization of deliberative and participatory democracy, starting from Habermas, looks at the activation of the civic sense and rational discussion identifying democracy in its bonds of social solidarity, legally mediated and guaranteed (Di Donato, 2018). The investigation on the link between democracy and language, in Habermas' theory of discourse, then refers to a broader question on the relationship between public space, discourse and reason, leaving space for an exchange of reasons that has priority over every strategic and self-referential representation of the social.

\section{N O T E S}

1 It should be noted that the translation of all the direct quotations of Habermas's works is mine.

2 About the relationships between Habermas and the Frankfurt School: S. Maffettone, Critica e analisi. Saggio sulla filosofia di Jürgen Habermas, Napoli 1980; H. Brunkhorst, Jürgen Habermas. Die Rächende Gewalt der kommunikativen Vernunft, in: J. Henningfeld - H. Jansohn, Philosophen der Gegenwart. Eine Einführung, Darmstadt 2005, pp. 198-15; J. G. Finlayson, Morality and Critical Theory. On the Normative Problem of Frankfurt School Criticism, "Telos", 2009, n. 146, pp. 7-41; U. Steinhoff, The Philosophy of Jürgen Habermas. A Critical Introduction, Oxford 2009. 
${ }^{3}$ Concerning the concept of public sphere in Habermas's theory, please see: C. J. Emden, D. Midgley, Beyond Habermas: Democracy, Knowledge, and the Public Sphere, New York - Oxford 2012; L. Dahlberg, The Habermasian Public Sphere and Exclusion, "Communication Theory", 2014 (XXIV), n. 1, pp. 21-41; A. Allen, The Public Sphere: Ideology and/or Ideal?, "Political Theory", 2012 (XL), n. 6, pp. 822-829; R. J. Bernstein, The Normative Core of the Public Sphere, "Political Theory", 2012 (XL), n. 6, pp. 767-778; J. Mansbridge, Conflict and Commonality in Habermas's Structural Transformation of the Public Sphere, "Political Theory", 2012 (XL), n. 6, pp. 789-801; S. Susen, Critical Notes on Habermas's Theory of the Public Sphere, "Sociological Analysis", 2011 (V), n. 1, 37-62.

\section{R E F E R E N C E S}

\section{Habermas's References}

Agire comunicativo e logica delle scienze sociali (1980). Bologna: il Mulino.

Dialogo su Dio e il mondo. Intervista con Edoardo Mendieta (1999). Teoria politica, $15(2-3), 419-38$.

Die Postnationale Konstellation (1998). Frankfurt am Main: Suhrkamp; it. transl. (2000b) La costellazione postnazionale. Mercato globale, nazioni e democrazia, Milano: Feltrinelli.

Faktizität und Geltung. Beiträge zur Diskurstheorie des Rechts und des demokratischen Rechtsstaats (1992), Frankfurt am Main: Suhrkamp; it. transl. (1996) Fatti e norme. Contributi a una teoria discorsiva del diritto e della democrazia, Milano: Guerini.

Für eine demokratische Polarisierung. Wie man dem Rechtspopulismus den Boden entzieht. Jürgen Habermas im Interview (2016). Blätter für deutsche und international Politik, 11, 35-42; it. transl. Jürgen Habermas. La risposta democratica al populismo di destra, Micromega, 2017, 2, 4-24.

Further Reflections on the Public Sphere (1992a), in: Calhoun C. (Eds.) Habermas and the Public Sphere (pp. 421-461). Cambridge - Massachusetts - London: MIT Press.

Habermas J. (1963) Teorie und Praxis, Neuwied: Luchterhand; it. transl. (1971) Teoria e prassi nella società tecnologica, Bari: Laterza.

Habermas J. Ratzinger J. (2005), Ragione e fede in dialogo. Le idee di Benedetto XVI a confronto con un grande filosofo Venezia: Marsilio.

Habermas J., Luhmann N. (1971) Theorie der Gesellschaft oder Sozialtecnologie, Frankfurt am Main: Suhrkamp; it. transl. (1983) Teoria della società o tecnologia sociale. Che cosa offre la ricerca del sistema sociale?, Milano: Etas Kom.

Habermas su web e sfera pubblica. Quello che la rete non sa fare (2014). Retrieved July 22, 2014, from http://www.reset.it. ISSN 2611-5883.

Habermas, J. (2006). Political Communication in Media Society: Does Democracy Still Enjoy an Epistemic Dimension? The Impact of Normative Theory on Empirical Research. Communication Theory, 16 (4), 411-426. 
Legitimationsprobleme im Spätkapitalismus (1973), Frankfurt am Main: Suhrkamp; it. transl. (1976) La crisi della razionalità nel capitalismo maturo, RomaBari: Laterza.

Moralbewußtsein und kommunikatives Handeln (1983), Frankfurt am Main: Suhrkamp; it. transl. (2000a) Etica del discorso, Roma-Bari: Laterza.

Public space and political public sphere - the biographical roots of two motifs in my thought (2004). In Commemorative Lecture, Nov. 11, 2004, 1-10, Kyoto.

Recht und Moral. (Tanner Lectures) (1992c); it. transl. Morale, diritto, politica, Torino: Einaudi.

Solidarietà tra estranei. Interventi su "Fatti e norme" (1997), Milano: Guerini.

Stato di diritto e democrazia: nesso paradossale di principi contraddittori? (2000c.) Teoria politica, 16(3), 3-17.

Tempo di passaggi (2004), Milano: Feltrinelli

Texte und Kontexte (1991), Frankfurt am Main: Suhrkamp; it. tr. (1993) Testi filosofici e contesti storici, Roma-Bari: Laterza.

Theorie des kommunikativen Handelns. Bd. II. Zur Kritik der funktionalistischen Vernunft (1981), Frankfurt am Main: Suhrkamp; it. transl. (1986) Teoria dell'agire comunicativo, vol. II. Critica della ragione funzionalistica, Bologna: il Mulino.

Vergangenheit als Zukunft (1992b), Zürich: Pendo-Verlag; it. transl. (1992) Dopo l'utopia, Venezia: Marsilio.

Zwischen Naturalismus und Religion. Philosophische Aufsätze (2005), Frankfurt am Main. Suhrkamp; it. transl. 2007 La condizione intersoggettiva, RomaBari: Laterza.

\section{Critical References}

"Discorso" e decisione. Il tentativo di Habermas di fondare una razionalità politica (1982), In Bovero M. (Eds.) Ricerche politiche. Saggi su Kelsen, Horkeimer, Habermas, Luhmann, Foucault, Rawls, (49-82) Milano: Angeli.

Accarino B. (1983) Comunicazione e democrazia in Habermas. Democrazia e diritto, 23(2) 103-111.

Agazzi E. (1983) Prefazione In Carmagnola F. (Eds.) La ragione emancipativa. Studi sul pensiero di Jürgen Habermas, (5-22). Palermo: Ila Palma.

Allen A. (2012) The Public Sphere: Ideology and/or Ideal? Political Theory, 40(6), $822-829$.

Bauman Z., Leoncini T. (2017) Nati liquidi, Milano: Sperling \& Kupfer.

Bernstein R. J. (2012) The Normative Core of the Public Sphere. Political Theory, 40(6), 767-778.

Bovero M. (Eds.) (1982) Ricerche politiche. Saggi su Kelsen, Horkeimer, Habermas, Luhmann, Foucault, Rawls, (49-82) Milano: Angeli. 
Brunkhorst H. (2005) Jürgen Habermas. Die Rächende Gewalt der kommunikativen Vernunft. In Henningfeld J., Jansohn H. (Eds.) Philosophen der Gegenwart. Eine Einführung, (198-215). Darmstadt: WBG Academic.

Bube T. (2008) Von der Kritischen Theorie zur Kritischen Hermeneutik? Jürgen Habermas' Transformationen der Verstehenslehre. In Faber R., Ziege E. M. (Eds.) Das Feld der Frankfurter Kultur und Sozialwissenschaften nach 1945, (139-66). Würzburg: Königshausen \& Neumann.

Carmagnola F. (1983) Ragion pratica. Nodi della tradizione filosofica in Habermas. In Carmagnola F. (eds.) La ragione emancipativa. Studi sul pensiero di Jürgen Habermas (25-90). Palermo: Ila Palma.

Carmagnola F. (Eds.) (1983) La ragione emancipativa. Studi sul pensiero di Jürgen Habermas. Palermo: Ila Palma.

Ceppa L. (2004) Il dibattito Denninger-Habermas sulla Costituzione. Teoria politica, 20(1), 133-143.

Dahlberg L. (2014) The Habermasian Public Sphere and Exclusion. Communication Theory, 24(1) 21-41.

Dahlgren P. (2005) The Internet, Public Spheres, and Political Communication: Dispersion and Deliberation. Political Communication, 22, 147-162.

Di Donato G. (2018) I luoghi della democrazia, Senso Comune, Retrived September, 16, 2018 from www.senso-comune.it.

Donolo C. (1971) Prefazione. In Habermas J. Teoria e prassi nella società tecnologica, (5-39). Bari: Laterza.

Emden C. J., Midgley D. (2012) Beyond Habermas: Democracy, Knowledge, and the Public Sphere. New York - Oxford: Berghahn Books.

Faber R., Ziege M. (2008) Das Feld der Frankfurter Kultur und Sozialwissenschaften nach 1945. Würzburg: Königshausen \& Neumann.

Ferrarese M. R. (2000) Le istituzioni della globalizzazione. Diritto e diritti nella società transnazionale. Bologna: il Mulino.

Finlayson J. G. (2009) Morality and Critical Theory. On the Normative Problem of Frankfurt School Criticism. Telos, 146, 7-41.

Florida A. (2017) Un'idea deliberativa della democrazia. Genealogia e principi. Bologna: il Mulino.

Geuss R. (1981) The Idea of a Critical Theory. Habermas and the Frankfurt School. Cambridge: Cambridge University Press; it. transl. (1989) L'idea di una teoria critica. Habermas e la Scuola di Francoforte. Roma: Armando.

Gorz A. (2003) L'immatériel. Connaissance, valeur et capital. Paris: Galilée; it. transl. (2003) L'immateriale. Conoscenza, valore e capitale. Torino: Bollati Boringhieri.

Grondin J. (1994) Die Hermeneutik und Habermas. In Grondin J. (Eds.) Der Sinn für Hermeneutik, 103-46. Darmstadt: WGB Academic.

Hart H.L.A. (1982) Essays in Jurisprudence and Philosophy. Oxford: Clarendon Paperbacks. 
Henningfeld J., Jansohn H. (2005) Philosophen der Gegenwart. Eine Einführung, Darmstadt: WBG Academic.

Il diritto al presente. Globalizzazione e tempo delle istituzioni (2002). Bologna: il Mulino.

Kalyvas A. (2001) The Politics of Autonomy and the Challenge of Deliberation. Thesis Eleven, 64, 1-19.

Keul H. K. (2002) Subjectivity and intersubjectivity. Remarks on the concept of freedom in Kant and Habermas. The Journal of Value Inquiry, 36(2-3), 25366.

Kirkpatrick G. (2003) Evolution or progress? A (critical) defence of Habermas's theory of social development, Thesis Eleven, 72, 91-112.

Luhmann N. (1996) Die Realität der Massenmedien, Opladen: Westdeutscher Verlag; it. transl. (2000) La realtà dei mass media, Milano: Angeli.

MacCormick D. N. (1981) H.L.A. Hart, London: Stanford University Press.

MacCormick D. N. (1994; I ed. 1978) Legal Reasoning and Legal Theory, Oxford: Oxford Scholarship; it. transl. (2001) Ragionamento giuridico e teoria del diritto, Torino: Giappichelli.

Maffettone S. (1980) Critica e analisi. Saggio sulla filosofia di Jürgen Habermas, Napoli: Liguori.

Manetti M. (2017) Costituzione, partecipazione democratica, populismo. In Report on the AIC Congress Democrazia oggi, Modena 10-11 November 2017.

Mansbridge J. (2012) Conflict and Commonality in Habermas's Structural Transformation of the Public Sphere. Political Theory, 40(6), 789-801.

Mazzei A. (2006) Networking Communication Research: la 56 Conferenza dell'ICA a Dresda. Retrieved June 27, 2006, from http://www.ferpi.it.

Minc A. (1998) Au nom de la lois. Paris: Gallimard.

Müller J. W. (2016) What is populism? University of Pennsylvania Press; it tr. (2017) Cos'è il populismo? Milano: Università Bocconi Editore.

Müller-Doohm S. (2015) Addio al passato. Habermas oltre la scuola di Francoforte. Retrieved July 10, 2015 from http://www.reset.it, ISSN 2611-5883.

Norval A. (2012) Don't Talk Back! The Subjective Conditions of Critical Public Debate. Political Theory, 40(6), 802-810.

Ostinelli M., Pedroni V. (1992) Fondazione e critica della comunicazione. Studi su Jürgen Habermas. Milano: Angeli.

Privitera W. (1983) Comunicazione ed emancipazione. La svolta linguistica della teoria di Jürgen Habermas. In Carmagnola F. (Eds.) La ragione emancipativa. Studi sul pensiero di Jürgen Habermas, (175-224). Palermo: Ila Palma.

Rasmussen D. M. (1990) Reading Habermas Oxford: Wiley-Blackwell; it. transl. (1993) Leggere Habermas, Napoli: Liguori.

Rasmussen T. (2008) The Internet and Differentiation in the Political Public Sphere. Nordicom Review, 29(2), 73-83. 
Rifkin J. (1995) The End of the Work. The Decline of the Global Labor Force and the Dawn of the Post-Market-Era, New York: Putnam Publishing Group; it. transl. (2002) La fine del lavoro. Il declino della forza lavoro globale e l'avvento dell'era post-mercato, Milano: Mondadori.

Rusconi G. E. (1980) Introduzione. In Habermas J. Agire comunicativo e logica delle scienze sociali, (7-30). Bologna: il Mulino.

Scheuerman W. E. (2006) Critical Theory beyond Habermas. In: Dryzek J. S., Honig B., Phillips A. (Eds.) The Oxford Handbook of Political Theory, (85105) Oxford (USA): Oxford University Press.

Sfera pubblica e democratizzazione (2001). Roma-Bari: Laterza.

Steinhoff U. (2009) The Philosophy of Jürgen Habermas. A Critical Introduction. Oxford: Oxford University Press.

Susen S. (2011) Critical Notes on Habermas's Theory of the Public Sphere. Sociological Analysis, 5(1), 37-62.

Urbinati N. (2014) La crisi europea tra populismi e nuove costituzioni. Retrieved April, 08, 2014 from http://www.reset.it, ISSN 2611-5883.

Vandenberghe F. (2002) Working out Marx. Marxism and the end of the work society. Thesis Eleven, 69, 21-46.

Waizbort R. (2004) Objectivity in Social Science. Toward a Hermeneutical Evolutionary Theory. Philosophy of the Social Sciences, 34(1), 151-62. 